\title{
IDENTIFIKASI KOMPONEN ISOFLAVONOID PADA BUAH BALANGKASUA (Lepisanthes alata (Blume) Leenh.)
}

\author{
(Identification Of Isoflavonoid Components In Balangkasua (Lepisanthes alata (Blume) Leenh.)
}

\author{
Susi \\ Jurusan Teknologi Industri Pertanian \\ Fakultas Pertanian, Universitas Lambung Mangkurat Banjarbaru \\ susi_tip@ulm.ac.id
}

Article Submitted : 23-04-2019

Article Accepted : 22-05-2019

\begin{abstract}
Balangkasua (Lepisanthes alata (Blume) Leenh.) is one of the exotic fruit typical of South Kalimantan, there are two kinds are yellow and purple-peel. This exotic fruit is still relatively low levels of consumption, this is because the harvest period is very short, not yet commercially grown, the growth area is in rural areas that are generally difficult to reach by public. Though the content of the nutritional value and phytochemical compounds that can be utilized. This research was aimed to determine the nutrient content in the pulp and peel and identify isoflavonoid component in the methanol extract of peel, pulp and seeds of purple peel balangkasua. Research result showed that pulp balangkasua contain protein of $8.40 \%$, crude fiber of $21.76 \%$, total acid of $26.90 \mathrm{mg}$ $\mathrm{KOH} / \mathrm{g}$ as well as vitamin $\mathrm{C}$ of $41.50 \mathrm{mg} / 100 \mathrm{~g}$, whereas in peel has a protein content of $4.20 \%$, crude fiber of $37.83 \%$, total acid of $13.47 \%$ and vitamin $\mathrm{C}$ of $38 \mathrm{mg} / 100 \mathrm{~g}$ ). Balangkasua was detected contain isoflavonoid compound there were equol and daidzein in seed, pulp was contained genestein, equol and genistin, and in the peel extract was contained genestein.
\end{abstract}

Keywords: balangkasua, Lepisanthes alata (Blume) Leenh., isoflavonoids, equol, daidzein, genestein

\section{PENDAHULUAN}

Buah-buahan lokal yang ada di Kalimantan pada umumnya merupakan tanaman tahunan dan populasinya semakin berkurang akibat budi daya yang kurang memadai. Kelangkaan tanaman juga disebabkan oleh umur berbuah yang terlalu lama, sehingga orang enggan untuk menanamnya. Permasalahan tersebut menyebabkan terjadinya pengikisan plasma nutfah.

Buah lokal Kalimantan Selatan juga banyak yang memiliki rasa asam, pulp (daging buah) dengan proporsi kecil dan lengket pada bijinya, hal ini sedikit menyulitkan jika dikonsumsi sebagai buah meja, salah satunya adalah buah
Balangkasua. Buah balangkasua berbentuk bulat dan memiliki warna kulit buah dua jenis yaitu berwarna kuning dan merah ungu (kondisi matang), sedangkan daging buah berwarna bening transparan dan berasa manis. Untuk meningkatkan pemanfaatan buah-buah eksotik Kalimantan Selatan tentunya diperlukan kajian lebih lanjut mengenai kandungan gizi dan senyawa fitokimia yang terkandung di dalamnya untuk lebih menggali potensi pemanfaatan buah lokal sebagai bahan baku olahan ataupun sumber pangan fungsional baik dari bagian, pulp buah, kulit maupun biji buah. Senyawa fitokimia salah satunya yang melimpah terdapat pada buah-buahan yaitu dari golongan flavonoid dimana senyawa ini 
dapat berperan sebagai antioksidan, antibakteri serta dapat menangkal penyakit degeneratif.

Flavonoid merupakan metabolit sekunder yang terdapat pada tanaman yang termasuk sebagai senyawa fenolik alam yang potensial sebagai antioksidan dan obat. Flavonoid memiliki kerangka dasar karbon yang terdiri dari 15 atom karbon, 2 -phenyl benzo $(\alpha)$ pyrane yang terdiri dari 2 cincin benzene (A dan $\mathrm{B}$ ) yang berikatan melalui cincin pyrane heterosiklik (C) sehingga membentuk C6-C3 - C6. Struktur C6-C3 - C6 dapat dilihat pada Gambar 1.

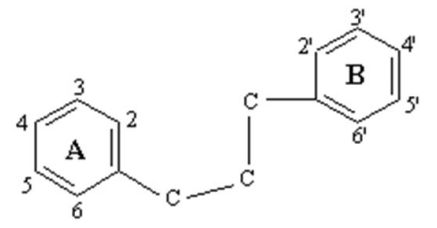

Gambar 1. sistem C6 -C3-C6

Susunan C6-C3-C6 phenyl benzopyran menghasilkan 3 struktur (berdasarkan posisi ikatan cincin aromatik pada benzopyrano (Chromano) yaitu 2phenylbenzopyrans atau Flavonoid, 3benzopyrans atau Isoflavonoid dan 4benzopyrans atau Neoflavonoid. Struktur kimia senyawa tersebut tertera pada Gambar 2.
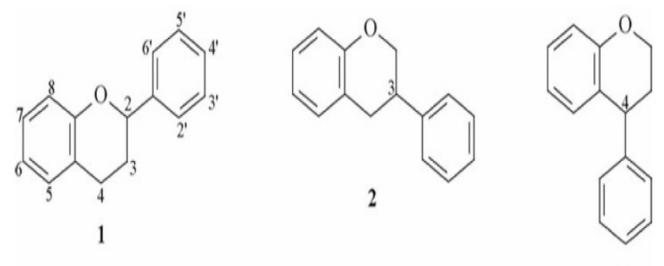

3

Gambar 2. Struktur phenylbenzopyran : 1) flavonoid; 2) isoflavonoid; 3) neoflavonoid

Flavonoid sendiri terbagi menjadi 6 subklass, tergantung pada keadaan oksidasi pusat pyran cincin: flavonol, flavon, flavanon, isoflavon, anthocyanidins dan flavanol (catechin dan proanthocyanidins). Flavonoid dan isoflavonoids telah menunjukkan banyak sifat biologi yang dapat menjelaskan sebagai pencegah timbulnya kanker (Bravo, 1998). Dalam beberapa tahun terakhir, cukup banyak kemampuan yang ditunjukkan antara lain menghambat siklus sel, proliferasi sel, dan stres oksidatif, dan menginduksi detoksifikasi enzim, dan kekebalan sistem. Flavonoid dan isoflavonoids, memiliki potensi aktivitas antikarsinogenik, bioavailabilitas, untuk memfasilitasi pengembangan strategi dan pendekatan baru dalam pengendalian kanker.

Isoflavonoids termasuk genistein dan daidzein, terbentuk terutama sebagai glikosida genistin dan daidzin, metabolisme dan bioavailabilitas isoflavonoids cenderung menjadi sangat penting untuk menunjukkan kemampuannya dalam membantu melindungi kesehatan manusia terhadap penyakit. Metabolisme isoflavon menjadi penting karena potensi metabolit isoflavon berbeda dari komponen induknya (Markiewicz et al. 1993) Metabolit equol daidzein adalah tiga kali lebih ampuh dari daidzein terhadap tumor endometrium. Equol juga merupakan antioksidan yang lebih kuat secara in vitro (Hodson et al. 1996; Mitchell et al. 1998; Arora et al. 1998; Wiseman et al. 1998).

Penelitian ini bertujuan untuk mengkaji kandungan gizi dan identifikasi senyawa fitokimia isoflavonoid pada buah dan kulit buah balangkasua yang nantinya diharapkan sebagai sumber informasi untuk pemanfaatan sebagai sumber pangan maupun pangan fungsional.

Penelitian ini diharapkan dapat memberikan informasi mengenai kandungan gizi dan senyawa fitokimia flavonoid pada buah dan kulit buah balangkasua sebagai salah satu buah eksotik khas Kalimantan yang pada akhirnya lebih meningkatkan pemanfaatan buah lokal sebagai sumber pangan fungsional. 


\section{METODE PENELITIAN}

\section{Bahan dan Alat}

Bahan utama yang digunakan pada penelitian ini meliputi buah Balangkasua dengan kulit warna merah yang diperoleh di Banjarbaru. Bahan kimia yang digunakan untuk analisis meliputi methanol, $\mathrm{Na}$ oksalat, larutan luff schoorl, $\mathrm{H}_{2} \mathrm{SO}_{4} \quad 26,5 \%$, Nathiosulfat $0,1 \mathrm{~N}, \mathrm{~K}_{2} \mathrm{~S}_{2} \mathrm{O}_{4}, \mathrm{HgO}, \mathrm{H}_{2} \mathrm{SO}_{4}$ pekat, $\mathrm{NaOH} 50 \%, \mathrm{HCl} 0,1 \mathrm{~N}$, phenolphthalein, $\mathrm{NaOH} 0,1 \mathrm{~N}$, amilum 1\%,larutan iodium $0,01 \mathrm{~N}$.

Alat yang digunakan meliputi glassware untuk analisis meliputi erlenmeyer, beaker glass, cawan mortar, buret, gelas ukur, labu ukur, labu pemisah, alat destruksi kjeldahl, seperangkat alat ekstraksi soxklet. oven, tanur, timbangan analitik dan HPLC-MS.

\section{Analisis Gizi}

Penelitian ini dilakukan dengan mencuci buah dan memisahkan antara kulit, buah (pulp) dan bijinya. Buah (pulp) dan kulit buah di analisis proksimat meliputi kadar air metode oven, kadar protein (Kjeldahl), kadar lemak (metode Soxlet), kadar abu (Gravimetri), kadar serat kasar dan kadar total gula (luff schoorl), kadar karbohidrat (luff schoorl), serta kandungan total asam (titrimetri), dan vitamin C (titrimetri) (Sudarmadji et al. 1997).

Analisis Isoflavonoid

\section{Preparasi Ekstrak Metanol}

Kulit, buah (pulp), dan biji buah balangkasua dikeringkan suhu $35^{\circ} \mathrm{C}$ hingga kering patah, kemudian dibubukkan. 5 gram bubuk bahan dimaserasi dengan menggunakan methanol $100 \mathrm{~mL}$ pada suhu ruang selama 24 jam. Tahapan ini diulang dua kali dan $200 \mathrm{ml}$ ekstrak dikumpulkan dan dievaporasi suhu $40^{\circ} \mathrm{C}$ menggunakan rotary vapor (Arunachalam and Subhahini 2011), hingga diperoleh ekstrak methanol pekat dari kulit, pulp dan biji balangkasua.

\section{Pengukuran Isoflavonoid}

Pengukuran kandungan isoflavonoid menggunakan Water Alliance High
Performance Liquid Chromatography Mass Spectroscopy (HPLC-MS) dengan jenis pelarut aquades, methanol, asam format dan acenonitril. Kondisi pengujian sebagai berikut :

$\begin{array}{ll}\text { Flow ramp } & : 0.10 \\ \text { Flow (ml/min) } & : 0.20 \\ \text { Stop Time (mins) } & : 35.0 \\ \begin{array}{l}\text { Column Temperature } \\ \left({ }^{\circ} \mathrm{C}\right)\end{array} & : 40.0 \\ \begin{array}{l}\text { Column Temperature } \\ \text { Limit }\left({ }^{\circ} \mathrm{C}\right)\end{array} & : 10.0 \\ \text { Min Pressure (Bar) } & : 0.0 \\ \text { Max Pressure (Bar) } & : 300.0 \\ \text { Stroke volume } & : 50.0 \mu 1 \\ \begin{array}{l}\text { Needle Depth (mm) } \\ \text { Sample Temperature }\end{array} & : 1.0 \\ \left({ }^{\circ} \mathrm{C}\right) & : 20{ }^{\circ} \mathrm{C}\end{array}$

HPLC dielusi dengan eluen HPLC dielusi menggunakan perbandingan eluen methanol : asam format (10:90), kemudian methanol : aquades $(10: 90)$ dan asam format : acetonitril $(95: 5)$. Standar yang digunakan merupakan standar campuran flavonoid 500 ppb dimana terdiri dari senyawa isoflavonoid utama berupa Daidzin, Genestein, Equol, Daidzein dan Genistin.

\section{HASIL DAN PEMBAHASAN}

\section{Kandungan Gizi Balangkasua}

Buah-buahan eksotik khas

Kalimantan Selatan masih merupakan tanaman yang tumbuh liar di hutan dan berbuah umumnya satu tahun sekali dengan masa musim yang cukup pendek. Buah Balangkasua merupakan salah satu buah eksotik khas Kalimantan Selatan dan masih jarang dikonsumsi oleh masyarakat. Jenis buah ini ada dua macam yang berkulit kuning dan berkulit ungu. Penampang buah, dan kulit buah balangkasua dapat dilihat pada Gambar 3. 

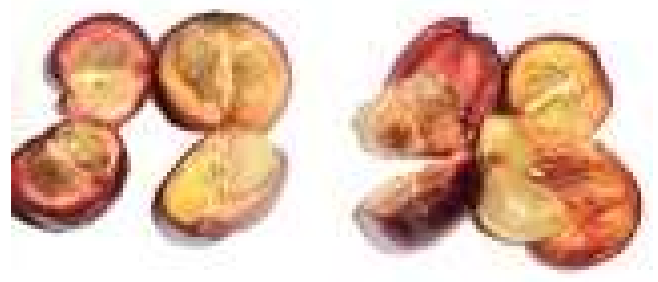

Gambar 3. Penampang buah balangkasua

Buah eksotis ini masih relatif rendah tingkat konsumsinya, hal ini dikarenakan periode panen yang sangat pendek, belum dibudidayakan secara komersil, area pertumbuhan masih pada area pedalaman sehingga umumnya sulit untuk dijangkau oleh masyarakat umum. Padahal kandungan nilai gizi pada buah-buah tersebut tidak kalah jika dibandingkan dengan buah pada umumnya.

Buah balangkasua memiliki rasa manis pada matang optimal. Untuk meningkatkan pemanfaatan buah ini dilakukan analisis kimia kandungan gizi pada buah dan kulit buah. Adapun hasil analisis kimia tertera pada Tabel 1.

Tabel 1 Analisis kimia pulp buah dan kulit buah balangkasua

\begin{tabular}{llcc}
\hline No & \multicolumn{1}{c}{ Kandungan Kimia } & Pulp buah & Kulit buah \\
\hline 1 & K. Air $(\%$ bb) & 67,18 & 63,47 \\
2 & K. Lemak $(\% b b)$ & 0,94 & 1,29 \\
3 & K. Protein $(\% b b)$ & 8,40 & 4,20 \\
4 & K. Serat Kasar $(\% \mathrm{bb})$ & 21,76 & 37,83 \\
5 & K. Abu $(\% \mathrm{bb})$ & 1,02 & 2,34 \\
6 & K. Karbohidrat $(\% \mathrm{bb})$ & 4,32 & 2,16 \\
7 & Total Asam $(\mathrm{mg} \mathrm{KOH} / \mathrm{g})$ & 26,90 & 13,47 \\
8 & Vitamin C $(\mathrm{mg} / 100 \mathrm{~g})$ & 41,50 & 38,00 \\
\hline
\end{tabular}

Buah balangkasua memiliki kandungan air 67,18\%, kadar lemak 0,94\%, kadar protein $8,40 \%$ dan serat kasar $21,76 \%$, sementara kadar karbohidrat sebesar hanya 4,32\%. Kadar total karbohidrat menggambarkan kandungan serat maupun kandungan gula di dalam buah. Sedangkan Antarlina (2009) menyebutkan bahwa daging buah balangkasua mengandung air sebesar $73,6 \%$ serta komponen kimia yang menonjol adalah protein $(3,1 \%)$ pati $(11,3 \%)$, total gula $(12,2 \%)$, dan karbohidrat (21,7\%). Komponen kimia yang menonjol pada buah balangkasua yakni kandungan serat dimana pada buah sebesar $21,76 \%$ sedangkan pada kulit buah sebesar 37,83\%.

Kandungan vitamin $\mathrm{C}$ buah balangkasua jumlahnya sebesar 41,50 $\mathrm{mg} / 100 \mathrm{~g}$ sedangkan pada kulitnya sebesar $38,0 \mathrm{mg} / 100 \mathrm{~g}$. Kulit balangkasua relatif tebal dengan bagian dalam kulit memiliki tekstur berserat dan lunak sehingga kemungkinan dapat dimanfaatkan lebih lanjut.

Keberadaan vitamin $\mathrm{C}$ selain sebagai sumber vitamin, vitamin $\mathrm{C}$ juga mampu berfungsi sebagai antioksidan. Buah yang banyak mengandung antioksidan dapat membantu dalam menurunkan kejadian penyakit degeneratif seperti kanker, artritis, arteriosklerosis, penyakit jantung, peradangan, disfungsi otak dan percepatan proses penuaan (Feskanich et al. 2000; Gordon 1996; Halliwell 1996). Sumber antioksidan dalam buah-buahan adalah polifenol dan Vitamin C, Vitamin A, B dan E dan karotenoid yang hadir pada tingkat lebih rendah dalam beberapa buah-buahan. polifenol, yang kebanyakan flavonoid, terutama dalam bentuk ester dan glikosida (Fleuriet dan Macheix, 2003). Wang et al. (1996) menyatakan bahwa kontribusi senyawa fenolik terhadap aktivitas 
antioksidan lebih besar dibandingkan vitamin C.

Vitamin $\mathrm{C}$ berperan penting dalam menghasilkan dan mempertahankan jaringan sel, memperkuat matriks sel tubuh secara keseluruhan (Gaby and Singh, 1991), sistem kekebalan tubuh melawan sel-sel tumor, mendukung sistem kardiovaskular melalui metabolisme lemak dan melindungi jaringan sel dari kerusakan radikal bebas (Schectman et al., 1991).

Sesuai Papp (2003), flavor buah lebih banyak dipengaruhi oleh kandungan asam dan kandungan gula. Kandungan total asam buah pada buah balangkasua $26.90 \mathrm{mg}$ $\mathrm{KOH} / \mathrm{g}$. Kandungan asam yang lebih dominan akan menyebabkan flavor dan rasa buah cenderung asam, demikian sebaliknya.

Kulit buah biasanya dianggap sebagai by product atau limbah yang tidak dimanfaatkan, padahal disisi lain kulit buah cukup banyak mengandung serat yang dapat berguna sebagai sumber serat pangan. Serat pangan meliputi komponen polisakarida non pati yakni seluolsa, hemiselulosa, pectin, glukasan, gum dan lignin (Gallaher and Schneeman 2001; Lamghari et al. 2000). Serat pangan dapat dimanfaatkan sifat nutrisinya dan dapat meningkatkan pemanfaatan by product sebagai bahan pangan. Diharapkan selanjutnya pemanfaatan serat pangan dari buah eksotik maupun kulit buahnya dapat menjadi bahan formulasi produk kaya serat pangan karena pangan dengan tinggi serat pangan mampu mencegah, mereduksi dan mengobati beberapa penyakit seperti diverticular dan penyakit jantung (Anderson et al. 1994), sebagai food ingredients. Untuk pengembangan pangan formulasi (GrigelmoMiguel and Mart_in-Belloso, 1999; Tudorica et al. 2002).

\section{Identifikasi Isoflavonoid}

Salah satu jenis buah balangkasua memiliki warna kulit buah berwarna merah dan semakin matang maka warna akan berubah menjadi ungu. Warna ungu ini identik dengan sumber antosianin sebagai salah satu jenis flavonoid. Isoflavon sebagai bagian dari flavonoid memiliki gugus fenil melekat posisi-3, sedangkan di flavon fenil tersebut melekat ke posisi 2-. Isoflavon terutama ditemukan dalam Leguminosae (khususnya di sub-keluarga Papilionoideae), isoflavon juga ditemukan dalam keluarga botani lainnya seperti Compositae, Iridaceae, Myristicaceae, dan Rosaceae. Isoflavon dapat bertindak meniru steroid dengan mengisi ruang stereokimia yang bisa diduduki oleh senyawa estrogenik. Hal ini spacial kimia yang membantu menjelaskan efek nutrisi suplemen herbal (Dweck 2006).

Buah balangkasua berwarna ungu dipisahkan masing-masing bagianyan yaitu kulit, pulp (buah) dan biji buah yang kemudian dikeringkan. Masing-masing bagian di maserasi dengan methanol. Adapun warna ekstrak yang diperoleh dari masing-masing ditunjukkan oleh Tabel 2 dan Gambar 4.

Tabel 2 Hasil ekstrak methanol buah balangkasua

\begin{tabular}{ccc}
\hline No & Jenis bahan & Warna ekstrak metanol \\
\hline 1. & Kulit buah & Merah-kecoklatan cerah \\
2. & Pulp buah & Kuning cerah \\
3. & Biji buah & bening \\
\hline
\end{tabular}




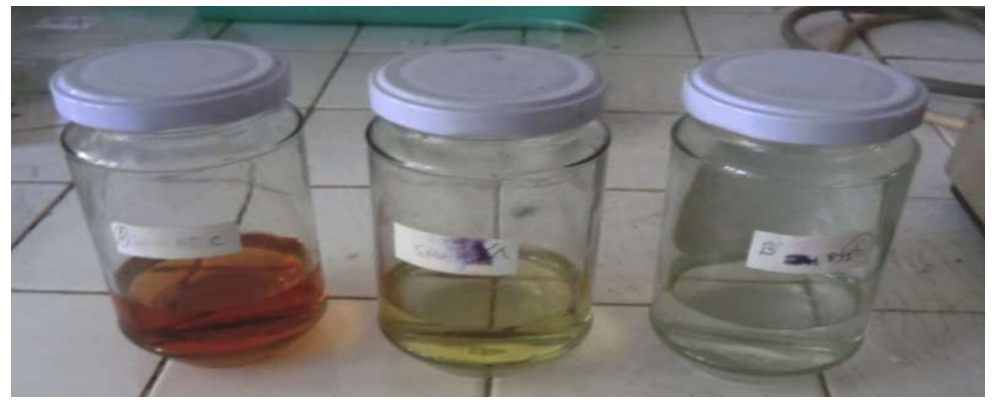

Gambar 4. Ekstrak methanol a) kulit ; b) pulp ; c) biji buah balangkasua

Ekstrak methanol masing-masing bahan dilakukan pengujian senyawa flavonoid dengan HPLC-MS. Hasil pengujian pada isoflavonoid standar dapat dilihat pada nilai retention time dan peak area dari senyawa isoflavonoid, hal tersebut dapat dilihat pada Gambar 5.

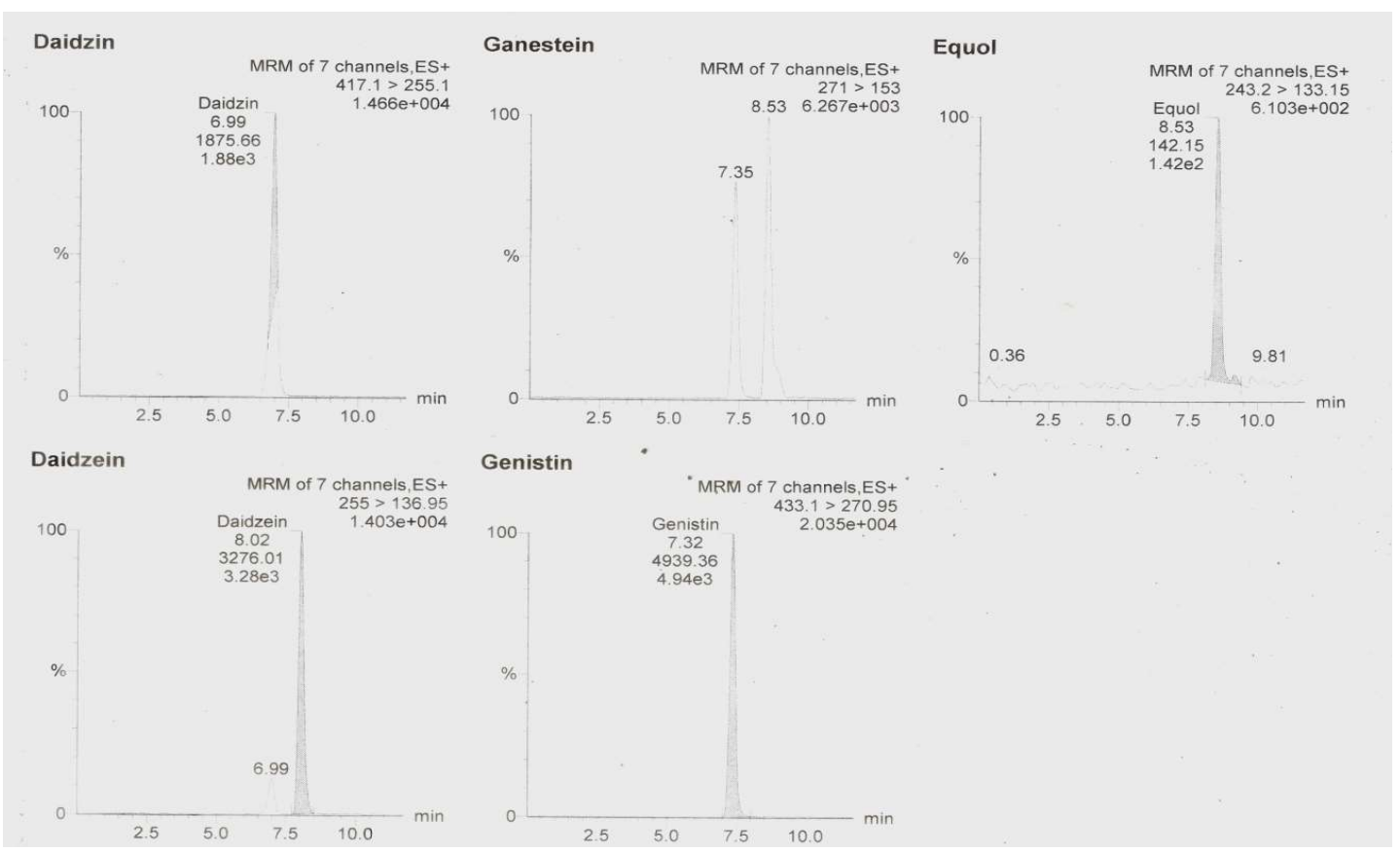

Gambar 5. Kromatogram HPLC Standar Daidzin, Genestein, Equol, Daidzein, dan Genistin

Larutan sampel yang diuji meliputi ekstrak methanol untuk kulit, pulp (buah) dan biji balangkasua. Ekstrak methanol biji balangkasua dari hasil pengujian terdeteksi mengandung jenis isoflavonoid equol dan daidzein. Equol terdeteksi pada retention time 8.14 menit dengan luas peak area 48.874 sedangkan daidzein terdeteksi pada retention time 7.99 menit dengan luas peak area 7.64. Berdasarkan perbandingan peak area sampel dan standar, maka equol dan daidzein pada ekstrak methanol biji buah balangkasua sebesar $34.38 \%$ dan $0.23 \%$. Kromatogram HPLC untuk equol dan daidzein pada ekstrak methanol biji buah balangkasua dapat dilihat pada Gambar 6. 


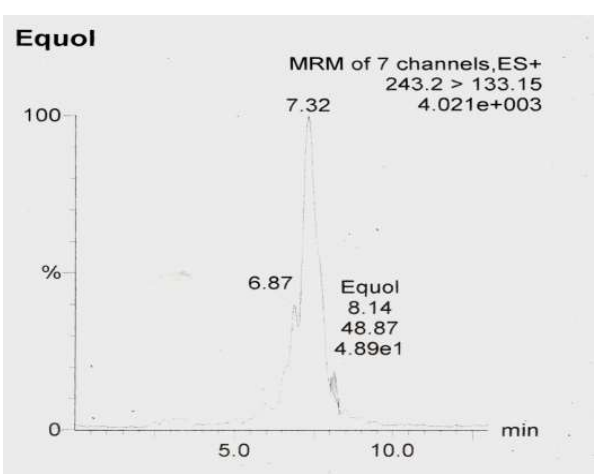

(a)

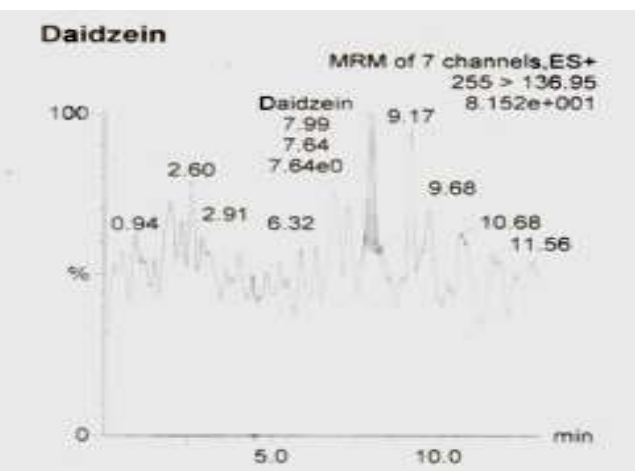

(b)

Gambar 6. Kromatogram HPLC : a) equol; b) daidzein pada esktrak methanol biji buah balangkasua

Pada ekstrak methanol pulp buah balangkasua terdeteksi senyawa isoflavonoid genestein, equol dan genistin masing-masing pada retention time 8,14 menit, 8,56 menit dan 7,38 menit. Adapun luas peak area genestein sebesar 10,492, equol sebesar 30,066 dan genistin 85,248. Jika dibandingkan dengan standar, maka konsentrasi equol dan genistin berturut-turut sebesar $21,15 \%$ dan $1,73 \%$. Kromatogram HPLC untuk genestein, equol dan genistin dapat dilihat pada Gambar 6. Pada ekstrak methanol kulit buah balangkasua hanya terdeteksi Genestein pada retention time 8,17 dan luas peak area 17,513, hal ini dapat dilihat pada Gambar 7.

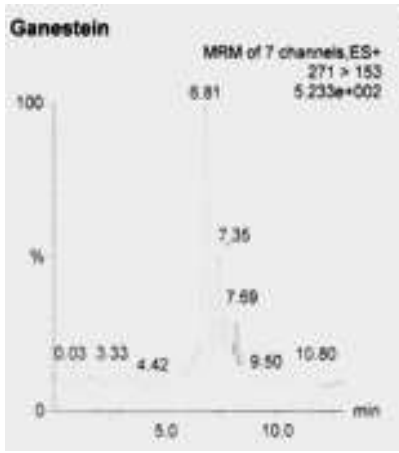

(a)

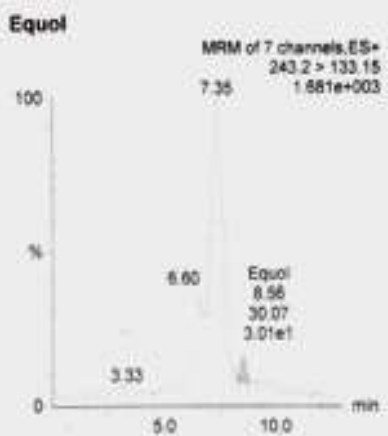

(b)

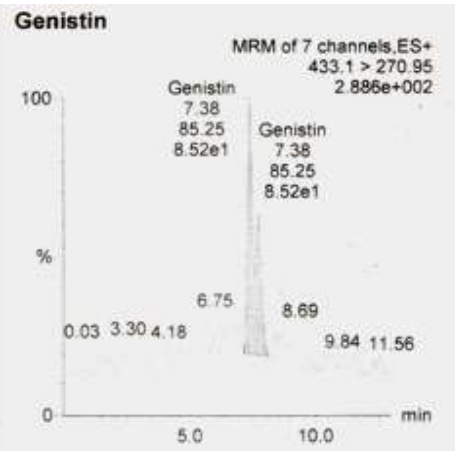

(c)

Gambar 7. Kromatogram HPLC a) genistein; b) equol dan c) genistin pada ekstrak methanol pulp buah balangkasua 


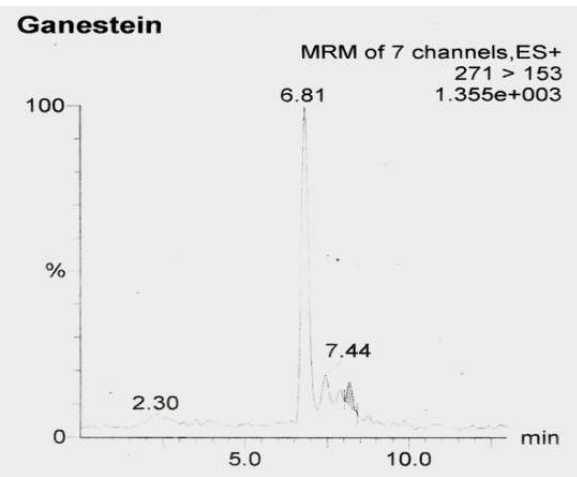

Gambar 8. Kromatogram HPLC genestein pada ekstrak methanol kulit buah

\section{Analisis LC-MS}

Analisis LC-MS untuk mengetahui berat molekul senyawa dan ditunjang dengan adanya fragmentasi ion molekul yang menghasilkan pecahan-pecahan spesifik untuk suatu senyawa berdasarkan $\mathrm{m} / \mathrm{z}$ dari masing-masing fragmen yang terbentuk. Terbentuknya fragmen-fragmen dengan terjadinya pemutusan ikatan apabila disusun kembali akan dapat menentukan kerangka struktur senyawa yang diperiksa.

Hasil analisis menggunakan LC-MS terhadap ekstrak methanol dari biji, pulp dan kulit buah ditunjukkan oleh spectra MS pada Gambar 9 dan tabulasi retention time, nilai $\mathrm{m} / \mathrm{z}$ pada Tabel 4. Sebagai acuan pendugaan senyawa yang terdeteksi pada ekstrak methanol biji, pulp dan kulit buah balangkasua.

Tabel 4. Tabulasi Retention time, nilai $\mathrm{m} / \mathrm{z}$ analit pada ekstrak biji, buah dan kulit buah balangkasua

\begin{tabular}{ccccccccc}
\hline $\begin{array}{c}\text { No } \\
\text { Analit }\end{array}$ & $\begin{array}{c}\text { Retention } \\
\text { time (RT) }\end{array}$ & $\begin{array}{c}\text { Nilai } \\
\mathrm{m} / \mathrm{z}\end{array}$ & $\begin{array}{c}\text { No } \\
\text { Analit }\end{array}$ & $\begin{array}{c}\text { Retenti } \\
\text { on time } \\
\text { (RT) }\end{array}$ & $\begin{array}{c}\text { Nilai } \\
\mathrm{m} / \mathrm{z}\end{array}$ & $\begin{array}{c}\text { No } \\
\text { Analit }\end{array}$ & $\begin{array}{c}\text { Retenti } \\
\text { on time } \\
\text { (RT) }\end{array}$ & Nilai m/z*) \\
\hline \multicolumn{7}{l}{ Ekstrak } \\
$\begin{array}{ccccccccc}\text { metanol biji } \\
1\end{array}$ & 2.13 & 73 & 1 & 2.13 & 74 & 1 & 2.13 & 143 \\
2 & 10.31 & 85 & 2 & 10.14 & 85 & 2 & 18.83 & 351 \\
3 & 10.99 & 445 & 3 & 10.82 & 445 & 3 & 19.51 & 353 \\
4 & 11.84 & 85 & 4 & 14.06 & 85 & 4 & 21.55 & 425 \\
5 & 14.06 & 85 & 5 & 15.76 & 621 & 5 & & \\
6 & 16.27 & 429 & 6 & 17.97 & 149 & 6 & & \\
7 & 17.12 & 425 & 7 & 18.83 & 351 & 7 & & \\
8 & 17.80 & 425 & 8 & 19.51 & 353 & 8 & & \\
9 & 18.83 & 351 & 9 & 20.87 & 383 & 9 & & \\
10 & 19.68 & 353 & 10 & 22.06 & 383 & 10 & & \\
11 & 22.06 & 383 & & & & & & \\
\hline
\end{tabular}

*) $\mathrm{LC} / \mathrm{MS} \mathrm{m} / \mathrm{z}=$ berat molekul yang terdeteksi pada puncak tertinggi spectra MS (ion molekuler) 


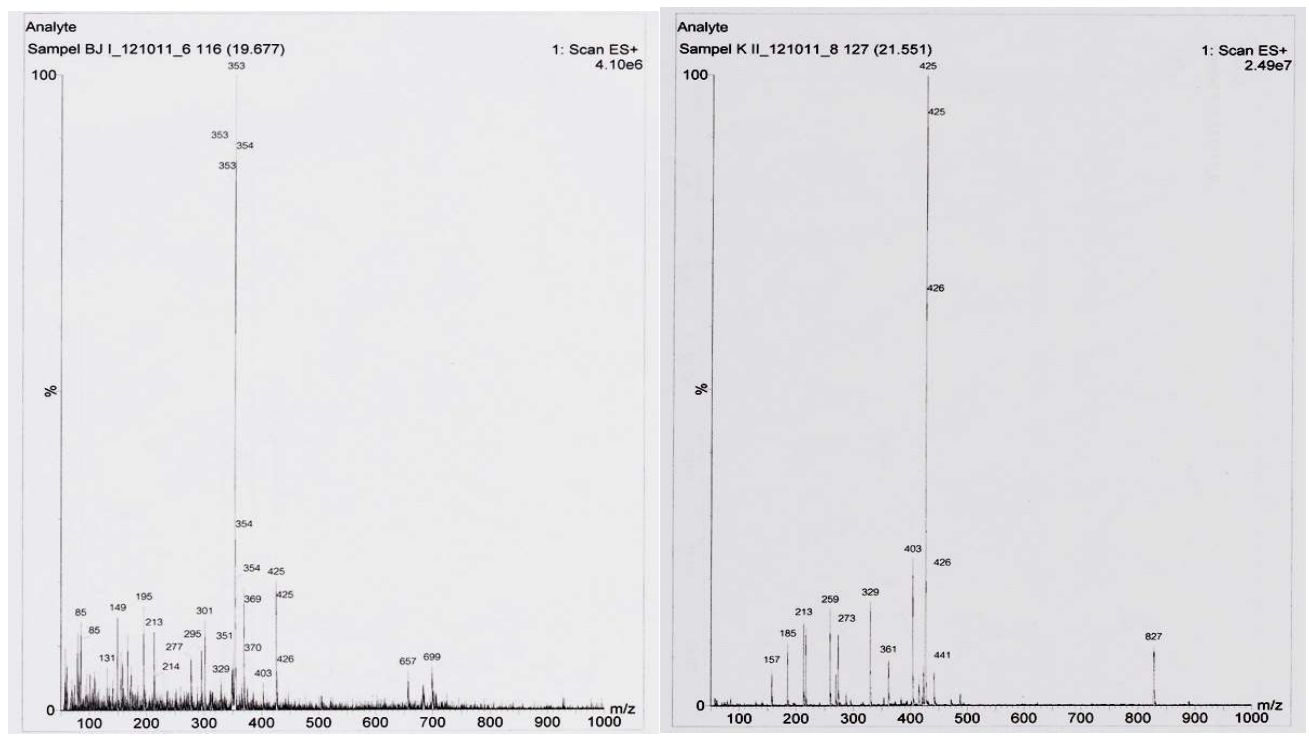

Gambar 9. Spektrum massa $\mathrm{m} / \mathrm{z}$ pada retention time 19. 68 (ekstrak methanol biji) dan $\mathrm{m} / \mathrm{z}$ pada retention time 21.55 menit (ekstrak methanol kulit)

Untuk identifikasi senyawa fenolat dan flavonoid dalam bahan tanpa standar komersial, baik spektrometer massa quadrupole tunggal dengan modus ESI dan triple quadrupole spektrometer massa tandem (MS/MS) dengan beberapa multiple-reaction monitoring mode (MRM) yang bekerja. MRM dapat memberikan spesifisitas dan sensitivitas yang tinggi, dan dengan demikian struktur asam fenolik diketahui atau flavonoid dapat dinilai berdasarkan pada $\mathrm{m} / \mathrm{z}$ dari kedua ion prekursor dan ion fragmen diperoleh melalui transisi massal (Prasain and Barnes 2007).

Berdasarkan pengukuran spektrum massa (MS), ekstrak metanol biji menunjukkan puncak-puncak pada $\mathrm{m} / \mathrm{z} 73$, $85,445,85,85,429,425,425,351,353$ dan 383. Dapat dikatakan massa molekul relatif berkisar pada 353. Sedangkan jika pada puncak dengan $\mathrm{m} / \mathrm{z} 429$, senyawa dengan massa molekul relative tersebut diduga sementara merupakan daidzein G2. Daidzein G2 atau disebut juga 7,4'-Dihydroxy-6methoxyisoflavone 7-O-(2-Omethylrhamnoside) dengan rumus molekul $\mathrm{C}_{23} \mathrm{H}_{24} \mathrm{O}_{9}$.
Pada ekstrak methanol pulp buah balangkasua memiliki spectrum massa dengan puncak-puncak pada $\mathrm{m} / \mathrm{z} 74,85,445$, $85,621,149,351,353,383$, dan 383 dengan rata-rata massa molekul relative 353 sedangkan pada ekstrak methanol kulit buah balangkasua memiliki spectrum massa dengan puncak lebih sedikit yaitu 143, 351, 353 dan 425 dengan massa molekul relative sebesar 425 .

Daidzein adalah bersifat padat yang hampir tidak larut dalam air. Rumus molekulnya adalah $\mathrm{C}_{15} \mathrm{H}_{10} \mathrm{O}_{4}$, dan berat molekulnya adalah 254,24 dalton. Daidzein juga dikenal sebagai 7-hidroksi-3- (4hidroksifenil)-4H-1-benzopyran-4-one dan 4',7 dihydroxyisoflavone. Daidzin, memiliki kelarutan dalam air lebih besar dari daidzein, adalah merupakan glukosida $7-\beta$ daidzein. Daidzein merupakan isoflavon yang juga diklasifikasikan sebagai suatu phytoestrogen karena merupakan senyawa nonsteroid yang memiliki aktivitas biologis seperti estrogen. Daidzein adalah aglikon (kadang-kadang disebut aglucon) dari daidzin. Isoflavon yang ditemukan secara alami sebagai glikosida daidzin dan sebagai glikosida 6 "-Omalonyldaidzin dan 6 "-O-acetyldaidzin. 
Daidzein adalah phytoestrogen, tetapi juga disebut estrogen fenolik, untuk membedakannya dari steroid estrogen seperti $17 \beta$-estradiol. Kegiatan phytoestrogen jauh lebih lemah daripada steroid estrogen, bervariasi $0,005-2 \%$. Sifat estrogenik ini tidak mencukupi dalam kekuatan untuk menggantikan estrogen steroid, tetapi mereka memiliki nilai signifikan untuk mengurangi efek penuaan dan meningkatkan kualitas kulit. (Dweck 2006). Senyawa isoflavon memiliki potensi phytoestrogen dengan urutan : >>estradiol coumestrol >8prenylnaringenin $>$ equol $>$ genistein $>$ biochanin A $>$ daidzein $>$ genistein glukuronat $*>$ daidzein glukuronat $*>$ formononetin (aktivitas senyawa bertanda * karena adanya aktivasi enzim yang ada dalam persiapan reseptor) (Dweck 2006).

\section{KESIMPULAN}

1. Buah balangkasua sebagai salah satu buah eksotik khas Kalimantan berpotensi untuk dimanfaatkan sebagai sumber serat pangan dimana untuk buah mengandung kadar air 67.18\% (bb), kadar lemak $0.94 \%$ (bb), kadar protein $8.40 \%$ ( bb) dan serat kasar $21.76 \%$ (bb), sementara kadar karbohidrat sebesar hanya $4.32 \%$ bb, dan vitamin C $41.50 \mathrm{mg} / 100 \mathrm{~g}$.

2. Kulit buah balangkasua memiliki kandungan air sebesar kadar air $63.47 \%$ (bb), kadar lemak 1.29\% (bb), kadar protein $4.20 \%$ ( $\mathrm{bb}$ ) dan serat kasar $37.83 \% \quad$ (bb), sementara kadar karbohidrat sebesar hanya $2.16 \%$ bb, dan vitamin C $38.0 \mathrm{mg} / 100 \mathrm{~g}$

3. Pada buah balangkasua terdeteksi memiliki kandungan senyawa isoflavonoid yaitu pada biji terdapat equol dan daidzein, pulp mengandung genestein, equol dan genistin, dan di kulit buah balangkasua terdeteksi mengandung genestein.

\section{DAFTAR PUSTAKA}

Anderson JW, Smith BM., Guftanson NS. 1994. Health benefit and practical aspects of high-fibre diets. American Journal of Clinical Nutrition 595 : 1242-1247.

Antarlina SS. 2009. Identifikasi Sifat Fisik dan Kimia Buah-buahan Lokal Kalimantan. Buletin Plasma Nutfah Vol.15 No.2

Arora A, Nair NG, Strasburg GM. 1998. Antioxidant activities of isoflavones and their biological metabolites in a liposomal system. Arch. Biochem. Biophys. 356 : 133-141.

Bravo, L. 1998. Polyphenols : Chemistry, Dietary Sources, Metabolism and Nutritional Significance. Nutrition Review $56 \quad$ (11) :317-333. DOI:10.1111/j.1753 4887.1998.tb01670.x

Dweck, AC. 2006. Isoflavones, Phytohormones and Phytosterols. J. Appl. Cosmetol. 24, 17-33.

Feskanich D. Ziegler RG. Michaud DS. Giovannucci EL. Speizer FE. Willett W C. 2000. Prospective study of fruit and vegetable consumption and risk of lung cancer among men and women. Journal of the National Cancer Institute 92 : 1812-1823.

Fleuriet A. dan Macheix JJ. 2003. Phenolic acids in fruits and vegetables. In C. A. Rice-Evans \& L. Packer (Eds.), Flavonoids in health and disease. Marcel Dekker Inc.

Gaby, S. K. dan Singh, V. N. 1991. Vitamin C-Vitamin intake and health: A Scientific Review, Gaby, S. K.; Bendich, A.; Singh, V. and Machlin, L. (eds.). Marcel Dedder, New York 
Gallaher D dan Schneeman BO. 2001. Dietary fiber. In: B. Bowman and R. Russel (Eds.). Present knowledge in nutrition $\left(8^{\text {th }}\right.$ Ed., $\left.805 p\right)$. Washington, DC: ILSI.

Grigelmo-Miguel, M. -Gorinstein, S. Martin-Belloso, O. 1999. Characterization of peach dietary fibre concentrate as a food ingredient. Food Chemistry. 65 : 175-181.

Gordon MH. 1996. Dietary antioxidants in disease prevention. Natural Product Reports 265-273.

Halliwell, B. 1996. Antioxidants in human health and disease. Annual Review of Nutrition $16: 33-50$.

Hodgson JM, Croft KD, Puddey IB, Mori TA, Beilin LJ. 1996. Soybean isoflavonoids and their metabolic products inhibit in vitro lipoprotein oxidation in serum. $J$. Nutr. Biochem. $7:$ : 664-669.

Lamghari, R., Sanchez, C., El Boustani, E., MaucourT, N. M., Sauvaire, Y., Mejean, L., dan Villaume, C. 2000. Comparison of effects of prickly pear (Opuntia ficus indica sp.) fruits, arabic gum and citrus pectin on viscosity and in vitro digestibility of casein. Journal of the Science of Food and Agriculture. 80 : 359-364

Markiewicz L, Garey J, Aldercreutz H, Gurpide E. 1993. In-vitro bioassays of non-steroidal phytoestrogens. $J$. Steroid Biochem. 45 : 399-405.

Mitchell JH, Gardner PT, Mcphail DB. 1998. Antioxidant efficacy of phytoestrogens in chemical and biological model systems. Arch. Biochem. Biophys. 360 : 142-148

Prasain, J.K. and Barnes, S. 2007. Metabolism and bioavailability of flavonoids in chemoprevention: current analytical strategies and future prospectus. Mol. Pharm.4 : 846-864.

Papp, J. 2000. Gyümölcstermesztési alapismeretek I. kötet. Mezőgazda Kiadó, Budapest. pp. 158.

Schectman G. Byrd JC., Hoffmann R. 1991. Ascorbic Acid Requirements for Smokers: Analysis of a Population Survey, American Journal of Clinical Nutrition, 53 (1) : 1466-1470

Sudarmadji S. Haryono B. dan Suhardi. 1997. Prosedur Analisa untuk Bahan Makanan dan Pertanian

Tudorica , C. M., Kuri, V., Brennan, C. S. (2002). Nutritional and physicochemical characteristics of dietary fiber enriched pasta. Journal of Agricultural and Food Chemistry. $50: 347-356$.

Wang H. Cao G. Prior RL. 1996. Total antioxidant capacity of fruits. $J$. Agric. Food Chem. 44 : 701-705.

Wiseman H, O’Reilly J, Lim P. 1998. Antioxidant properties of the isoflavone phytoestrogen functional ingredient in soy products. In Functional Foods, the Consumer, the Products and the Evidence (M Sadler, M Saltmarsh, editors), Royal Society of Chemistry, Cambridge, pp. 80-86. 